\title{
ИСТОРИЯ СТАНОВЛЕНИЯ КАФЕДРЫ НЕЙРОХИРУРГИИ В БАШКИРСКОМ ГОСУДАРСТВЕННОМ МЕДИЦИНСКОМ УНИВЕРСИТЕТЕ
}

\section{Деревянко Христина Петровна}

к.М.н, доцент

Сафин Шамиль Махмутович д.м.н., профессор, заведующий кафедрой Блинова Наталья Михайловна к.м.Н., доцент

ФГБОУ ВО «Башкирский государственный медицинский университет» Минздрава России

Аннотация: в статье представлены основные этапы развития кафедры нейрохирургии и медицинской реабилитации с курсом ИДПО Башкирского государственного медицинского университета. В публикации приводятся автобиографические данные основателей кафедры и опыт преподавания дисциплины. С момента основания и до сегодняшних дней кафедра является лидером среди клинических дисциплин Башкирского государственного медицинского университета. Кафедра имеет опыт обучения иностранных студентов и ординаторов с использованием английского языка - посредника.

Ключевые слова: нейрохирургия, Клара Гумеровна Валиева, история медицины, Башкирский государственный медицинский университет, педагогика.

\section{HISTORY OF FORMATION OF THE DEPARTMENT OF NEUROSURGERY IN THE BASHKIR STATE MEDICAL UNIVERSITY}

\section{Derevyanko Khristina Petrovna Safin Shamil Mahmutovich Blinova Natalya Mikhailovna}

\begin{abstract}
The article presents the main stages in the development of the Department of Neurosurgery and Medical Rehabilitation with the course of the PE of the Bashkir State Medical University. The publication provides autobiographical data of the founders of the department and the experience of teaching the discipline.
\end{abstract}


From the moment of foundation to the present day, the department has been a leader among the clinical disciplines of the Bashkir State Medical University. The department has experience in teaching foreign students and residents in English.

Key words: neurosurgery, Klara Gumerovna Valieva, history of medicine, Bashkir State Medical University, pedagogy

В сентябре 2014 года начала свою работу кафедра медицинской реабилитации с курсами нейрохирургии и рефлексотерапии ИДПО Башкирского государственного медицинского университета. Со дня открытия на кафедре преподавали медицинские реабилитологи, нейрохирурги, неврологи, рефлексотерапевты. Учитывая высокий уровень нейрохирургической службы в республике Башкортостан и профессионализм нейрохирургов кафедры не только в хирургической, но и педагогической деятельности со стороны студентов и выпускников появился запрос в углубленном преподавании нейрохирургической дисциплины. Вскоре кафедра была переименована в кафедру нейрохирургии и медицинской реабилитации с курсом ИДПО. Востребованность на получение знаний по нейрохирургии со стороны молодых выпускников не случайно, нейрохирургическая служба имеет давнюю историю у истоков которой стояла профессор кафедры неврологии Нинель Андреевна Борисова и основоположник нейрохирургии в Башкортостане Клара Гумеровна Валиева [1]. Профессор Нинель Андреевна Борисова и заслуженный нейрохирург Республики Башкортостан Клара Гумеровна Валиева внесли вклад в изучение дизонтогенетической патологии нервной системы, исследуя клинические проявления и эффективность хирургического лечения гидроцефалии (д.м.н. Ш.М. Сафин, к.м.н. А.Р. Файзуллин), краниовертебральных аномалий - аномалия Арнольда Киари (к.м.н. Рашид Имад Мухамад), аномалии атланта Киммерле (к.м.н. Г.М. Мусина и Р.Т. Шарипов). Наряду с исследованием эпидемиологии заболеваний, изучены характер метаболических, иммунологических изменений и нарушений микроэлементного состава при различных заболеваниях, разработаны новые подходы к консервативному и хирургическому лечению. Кларой Гумеровной в начале 90-х годов была проделана большая работа по сотрудничеству и поиску новых нейрохирургических решений в помощи населению проживающих в Республике Башкортостан. Был приглашен один из ведущих нейрохирургов Северо-Западного Федерального медицинского исследовательского центра 
им. В.А. Алмазова - проф., д.м.н. В.А. Хачатрян. Жители Республики со сложными нейрохирургическими патологиями, смогли получить помощь, не покидая родную Республику. Так же параллельно проводились обучающие мастер классы для хирургов. Организаторский талант Клары Гумеровны позволил впервые в стране внедрить в практику реабилитация пациентов с позвоночно-спинальной травмой тем самым снизить уровень инвалидизации пациентов $[2,3]$.

Педагогическая, лечебная и научная работа на кафедре нейрохирургии развивалась стремительно успешно завоевав признание и авторитет со стороны студентов и молодых врачей и вскоре стала базой для обучения российских и зарубежных молодых врачей.

Сегодня кафедру нейрохирургии и медицинской реабилитации с курсом ИдПО БГМУ возглавляет Сафин Шамиль Махмутович - доктор медицинских наук, заслуженный врач Республики Башкортостан, нейрохирург высшей квалификационной категории, руководитель центра специализированного вида медицинской помощи - нейрохирургии в Республике Башкортостан, член правления Ассоциации нейрохирургов России, руководитель нейрохирургической службы республики, главный внештатный специалист Министерства Здравоохранения Республики Башкортостан, заслуженный врач Республики Башкортостан, почетный профессор Харбинского медицинского университета (Китай), член правления Всемирной ассоциации нейрохирургов, член Российской и Европейской ассоциаций нейрохирургов, а также Башкирского регионального отделения Союза реабилитологов России. С его участием созданы: Региональный центр нейрохирургии, Региональный сосудистый центр, Региональный травматологический центр Республики Башкортостан, отделение нейрореанимации, отделение восстановительной медицины и ранней нейрореабилитации, а также первичные центры реабилитации в лечебно - профилактических учреждениях Республики Башкортостан. В 2021 г. профессору Ш.М. Сафину за заслуги в практической нейрохирургии и научные достижения, а также за выполнение лучшей операции года под контролем МРТ пациенту с болезнью Паркинсона присвоено звание лауреата премии «Золотой скальпель-2020».

Цитируя известного философа Иоганна Вольфганга Гёте «Настоящий ученик учится развивать неизвестное с помощью известного и тем самым приближается к учителю», хочется привести пример широкого использование компьютерных технологии в обучении молодых врачей. Так студенты, 
ординаторы и аспиранты кафедры имеют возможность оттачивать практические навыки на манекенах-симуляторах в мультипрофильном аккредитационном-симуляционном центре при БГМУ.

В 2018 году одним из путей совершенствования образовательного процесса стало преподавание нейрохирургии и медицинской реабилитации студентам с использованием языка посредника. Перед профессорско-преподавательским составом кафедры была поставлена задача не только использовать язык посредника. Но оценивать и применять на кафедре лучшие зарубежные методики преподавания, выявленные в ходе анализа англоязычной литературы [4].

Приоритетными направлениями научных исследований кафедры являются: патология краниовертебральной области, сосудистые мальформации сосудов головного и спинного мозга, гидроцефалии, нейроонкология, реабилитация пациентов при нейрохирургической патологии.

Таким образом, за восемь лет сложился дружный, творческий коллектив, который внедряет в клиническую практику новые высокотехнологические методы диагностики и исследования, принимает участие в междунарожных и российских конференциях, пользуется заслуженным уважением коллег, студентов, аспирантов, выпускников.

\section{Список литературы}

1. Бакиров Б.А., Сафин Ш.М., Кутлубаев М.А., Деревянко Х.П., Блинова Н.M., Афанасьева О.Г. Клара Гумеровна Валиева - врач, педагог, ученый. Журнал «Вопросы нейрохирургии» имени Н.Н. Бурденко. 2020;84(1):118-119.

2. Головная боль при мальформации Киари в детском возрасте / Ш.М. Сафин, А.Г. Тимершин, Х.П. Деревянко, И.М. Гилемханова // Российский вестник перинатологии и педиатрии. - 2020. - Т. 65. - № 4. С. 292.

3. Сафин Ш.М. Гипотезы генетических аспектов патогенеза аномалии Киари 1-го типа / Ш.М. Сафин, И.М. Гилемханова, Х.П. Деревянко // Вестник неврологии, психиатрии и нейрохирургии. - 2020. - № 5. - С. 25-33. DOI 10.33920/med-01-2005-03. 
4. Деревянко Х.П. Современное лекционное занятие глазами студентов-иностранцев медицинского университета / Х.П. Деревянко, Ш.М. Сафин, Р.С. Фаршатов // Социальные технологии работы с молодежью в условиях становления цифрового общества : сборник статей IV Международной научно-практической конференции, Уфа, 13-14 ноября 2019 года. - Уфа: Башкирский государственный университет, 2019. - С. 92-94.

(C) Х.П. Деревянко, Ш.М. Сафин, Н.М. Блинова, 2022 